\title{
EFFECTIVENESS OF EU LAW AND POLICY ON VERTICAL RESTRAINTS AT PROTECTING COMPETITION
}

\author{
PUYA RAAD, LL.M. *
}

\section{INTRODUCTION}

Questioning the effectiveness of EU competition policy and law makes sense because, since the Peugeot case ${ }^{1}$ in October 2005, no further vertical agreement case has been found by the Commission to have infringed Art. 101(1) TFEU. ${ }^{2}$ Although this fact might reveal that undertakings have been convinced to behave legally, it also might rely on the changes which EU competition policy and case law have adopted in recent years, such as the effects-based approach to deal with vertical agreements or the introduction of block exemptions in $1999^{3}$ by the Commission. Most vertical agreements fall outside Art. 101(1) TFEU because they are exempted or can be otherwise justified for economic and pro-competitive reasons. ${ }^{4}$

Besides Art. 101 and 102 TFEU, the scope of EU competition law has been highly defined by European Court of Justice (ECJ) case law, Commission documents and regulations. Namely, the Commission's Guidelines on Vertical Restraints from $2010^{5}$ (new Guidelines), the Block Exemption Regulation (EU) No. 330/2010 6 (BER) and Guidelines on the application of Art. $81(3)^{7}$ which consolidate European policy regarding vertical agreements. The following section, $\mathrm{B}$, will concentrate on typical

DOI: 10.2478/wrlae-2013-0047

* Mr Puya Raad, LL.M. (Frankfurt), Professor's assistant, Centre for Law and

Administration, Brandenburg University of Technology, Cottbus-Senftenberg, Germany;

p.raad@b-tu.de

${ }^{1}$ Case T-450/05, Peugeot $v$ Commission [2009] ECR II-2533.

${ }^{2}$ Richard Wish and David Bailey, 'Regulation 330/2010: The Commission's New Block Exemption for Vertical Agreements’ [2010] CML Rev 1751 (1760).

${ }^{3}$ Commission, 'Commission Regulation (EC) No. 2790/1999 of 22 December 1999 on the application of Article 81(3) of the Treaty to categories of vertical agreements and concerted practices' [1999] OJ L336/21.

${ }^{4}$ Richard Wish and David Bailey, 'Competition Law' (7 $7^{\text {th }}$ edn, OUP 2012) 637.

${ }^{5}$ Commission, 'Guidelines on Vertical Restraints' [2010] OJ C130/1.

${ }^{6}$ Commission, 'Commission Regulation (EU) No. 330/2010 of 20 April 2010 on the application of Article 101 (3) of the Treaty on the Functioning of the European Union to categories of vertical agreements and concerted practices' [2010] OJ L102/1. See also Frank Wijckmans and Filip Tuytschaever, 'Vertical Agreements in EU Competition Law' $(2$ nd $e d n$, OUP 2011) 87.

${ }^{7}$ Commission, 'Guidelines on the application of Article 81(3) of the Treaty' [2004] OJ C101/97. 
vertical agreements, discussing their justifiability as well as the accompanying case law. In section $\mathrm{C}$, a conclusion will be drawn based on the analysis given.

\section{TYPICAL VERTICAL RESTRAINTS AND COMPETITION LAW}

The Commission finds in its new Guidelines that 'vertical restraints may have positive effects by, in particular, promoting non-price competition and improved quality of services'. ${ }^{8}$ However, it also notes that vertical restraints may result in the anti-competitive foreclosure of other suppliers and buyers, softening of competition and facilitation of collusion as well as the creation of obstacles to market integration. ${ }^{9}$ Some types of restraint will be discussed in the following paragraphs.

\section{A. Anti-competitive vertical restraints by object}

a) Absolute territorial protection and export bans

In Consten and Grundig in 1966, the ECJ held that agreement clauses which try to isolate national markets and to impede intra-brand competition or parallel trade restrict competition by object are illegal. ${ }^{10}$ The Commission followed this strict line; for example, in 1998 it imposed a $€ 102$ million fine (reduced to $€ 90$ million on appeal) on Volkswagen in respect of its contractual practices to prevent distributors from selling outside their distribution territories. ${ }^{11}$ Monti discussed this approach in 2002 and underpinned the Advocate General's economic argument in Consten and Grundig ${ }^{12}$ that without territorial protection, no reasonable distributor would take the risk of investing in a new and uncertain market if he knew that a free rider, who does not share the introduction costs of the product, would later enter the market and sell the product, taking advantage of the distributor's marketing efforts. ${ }^{13}$

In its new Guidelines, the Commission holds that 'it may be necessary to provide territorial protection for the distributor so that he can recoup ... [his] investments by temporarily charging a higher price. Distributors based in other markets should then be restrained for a limited period from selling in the new market.' 14 The new policy is not therefore a formalistic approach, unlike in the past, but an effects-based one, which allows legal and economic justifications.

\section{b) Resale Price Maintenance (RPM)}

Before moving on to the effects-based policy, RPM, being a hardcore restriction on competition, was taken very seriously by the Commission and

\footnotetext{
${ }^{8}$ Commission (n 5) para 106.

${ }^{9}$ Commission (n 5) para 100.

${ }^{10}$ Joined Cases C-56 and 58/64, Etablissements Consten SA \& Grundig-Verkaufs-GmbH v Commission [1966] ECR 299 (343).

${ }^{11}$ Alison Jones and Brenda Sufrin, 'EU Competition Law' (Text, Cases, and Materials, $4^{\text {th }}$ edn, OUP 2011) 656.

${ }^{12}$ Etablissements Consten SA \& Grundig-Verkaufs-GmbH v Commission (n 10).

${ }^{13}$ Giorgio Monti, ‘Article 81 EC and Public Policy' [2002] CML Rev 1057 (1065).

${ }^{14}$ Commission (n 5) para 107.
} 
led to the imposition of significant fines. ${ }^{15}$ The new Guidelines, however, recognise three situations in which RPM could cause efficiencies to the benefit of consumers and so may be exempted under Art. 101(3): 'Firstly, resale price maintenance may be necessary to induce distributors to promote a new product when it is not practical to achieve this result contractually. Secondly, resale price maintenance may be necessary to organise short-term (six to eight weeks) promotions in distribution agreements belonging to a franchise system or similar distribution system applying a uniform distribution system (arguably, selective distribution systems). Thirdly, the parties may demonstrate that resale price maintenance is a means to avoid free riding of pre-sale services, in particular, in the case of experienced resellers or complex products'. ${ }^{16}$

Reindl criticises the Commission's approach towards RPM and demands a distinction between harmful and efficient RPM. Without such a distinction and in order to stay faithful to the economic approach, case law should determine what constitutes an infringement of Article 101(1). ${ }^{17}$ Kyprianides agrees that RPM may result in some efficiencies, but he supports the general presumption of RPM being a hardcore restriction and refers to the lack of 'solid empirical evidence' as to whether the efficiencies of RPM can fully outweigh the disadvantages and harm it sometimes causes. ${ }^{18}$

\section{c) The future of hardcore restrictions or restrictions by object}

Jones et al. have found that the Commission and the ECJ have a different understanding of restrictions by object. ${ }^{19}$ The Commission states that restrictions by object are those which 'by their very nature' are likely to produce negative effects on the market and to jeopardise the objectives pursued by EU competition rules. Because of their high potentiality to produce negative effects, there is no need to assess their 'actual effects on the market'. ${ }^{20}$ However, the ECJ finds that to determine whether conduct is 'by its very nature' injurious to competition or anti-competitive by nature (restrictive by object), 'regard must be given inter alia to the content of its provisions, the objectives it seeks to attain and the economic and legal context of which it forms a part'. ${ }^{21}$

King supports Jones' findings and refers to the Louis Erauw ${ }^{22}$ case where the Court found that even absolute territorial protection can fall outside

\footnotetext{
${ }^{15}$ See Jones and Sufrin (n 11) 657.

${ }^{16}$ Gianni De Stefano, 'The new EU "Vertical Restraints Regulation": navigating the vast sea beyond safe harbours and hardcore restrictions' [2010] ECLR 487 (489).

17 Andreas P Reindl, 'Resale Price Maintenance and Article 101: Developing a more sensible analytical approach' [2010] Fordham Int'1 L. J. 1300 (1321).

${ }^{18}$ George P Kyprianides, 'Should resale price maintenance be per se illegal?' [2012] ECLR $376(383)$.

${ }^{19}$ Alison Jones, 'Left behind by modernisation? Restrictions by object under Article 101 (1)' [2010] ECJ 649 (656). See also Craig Callery, 'Should the European Union embrace or exorcise Leegin's “rule of reason”?' [2011] ECLR 42 (45).

${ }^{20}$ Commission (n 7) para 21.

21 Joined Cases C-501, 513, 515 \& 519/06, GlaxoSmithKline Services Unlimited $v$ Commission [2009] ECR I-9291, para 58.

22 Case C-27/87, SPRL Louis Erauw-Jacquery v La Hesbignonne [1983] ECR 1919, paras $10-11$.
} 
the scope of Art. 101(1). ${ }^{23}$ In the recent BIDS case, the Court did not apply the Commission's categorisation of object and effect cases, and it states that to decide whether an arrangement is an anti-competitive restriction by object, the agreement's content and the economic context are to be examined. ${ }^{24}$ Therefore it is doubtful whether case law reflects the Commission's policy of object and effect cases and in taking this further the existence of object cases in the near future may be in question. Bailey acknowledges that in the Pierre Fabre case ${ }^{25}$ the ECJ for the first time saw an 'objective justifiability' for a restriction by object. ${ }^{26}$ Thus, it is no wonder that some authors call the new approach to EU competition law a 'more analytical approach' rather than effects-based. ${ }^{27}$

\section{B. Anti-competitive vertical restraints by effect}

Where a vertical agreement does not infringe Art. 101 by object, it is necessary to look at the effect of the agreement. Only then will it be possible to identify a factual restriction to competition. ${ }^{28}$

\section{a) Selective distribution/exclusive distribution}

Producers of branded products usually establish a distribution system in which the products can be bought and resold only by authorised distributors and retailers to members of the system or to the final consumer. ${ }^{29}$ The Commission states in its new Guidelines that these distribution systems may restrict intra-brand competition, foreclose other competitors' access to the market, soften competition and facilitate collusion between suppliers or buyers. ${ }^{30}$ On the other hand, through distribution structures suppliers try to create and maintain a particular brand image of their product and ensure that the sale of their goods is accompanied by the provision of pre-sale retail services. $^{31}$

In the Metro I case the ECJ upheld the Commission's opinion that selective distribution accords with Art. 101(1) provided that: (1) resellers are chosen on the basis of objective criteria of a qualitative nature relating to the technical qualifications of the reseller and its staff and the suitability of its trading premises, and that (2) such conditions are laid down uniformly for all potential resellers and are not applied in a discriminatory fashion ${ }^{32}$ (qualitative selective distribution). Other selective distribution systems may infringe Art. 101(1), but they may take advantage of the block exemption in

${ }^{23}$ Saskia King, 'The Object Box: Law, Policy or Myth' [2011] ECJ 269 (281).

${ }^{24}$ Case C-209/07, Competition Authority v Beef Industry Development Society Ltd and Barry Brothers (Carrigmore) Meats Ltd. [2008] ECR I-8637, para 16.

${ }^{25}$ Case C-439/09, Pierre Fabre Dermo-Cosmétique SAS v Président de l'Autorité de la Concurrence and Others [2011] ECR I-9419, para 39.

${ }^{26}$ David Bailey, 'Restrictions of Competition by Object under Article 101 TFEU' [2012] CML Rev 559 (580).

${ }^{27}$ King (n 23) 277.

${ }^{28}$ Jones and Sufrin (n 11) 662.

${ }^{29}$ Wish and Bailey (n 4) 641.

${ }^{30}$ Commission (n 5) para. 175.

${ }^{31}$ Philip Marsden and Peter Whelan, 'Selective distribution in the age of online retail' [2010] ECLR 26 (27)

${ }^{32}$ Case C-26/76, Metro-SB-Grossmärkte GmbH v Commission [1977] ECR I-1875, para 21. 
the BER if the market share does not exceed 30 per cent or they may satisfy Art. 101(3) on an individual basis. ${ }^{33}$

Another distribution agreement which raises anti-competitive concern is an exclusive distribution agreement, in which the manufacturer appoints a sole distributor for a particular area. Hereby the distributor is sheltered from intra-band competition and will be encouraged to incur expenditure promoting and advertising the product, safe from other distributors' free riding on that expenditure. ${ }^{34}$ In the STM case the ECJ held that exclusive agreements will not restrict competition if it is necessary to penetrate a new market. ${ }^{35}$

By the use of exclusive distribution practices the Commission fears the reduction of intra-brand competition and facilitation of price discrimination in different territories as well as softening competition, easing collusion or foreclosure of the market to the detriment of other competitors. ${ }^{36}$ It states, however, that the loss of intra-brand competition can only be seen as problematic if inter-brand competition is limited. This concern is assumed to be given only if the supplier has a strong position on the market. ${ }^{37}$

Jones and Suffrin state that the requirements set out by the ECJ are difficult to apply in practice, and identical restrictions have been labelled as qualitative in some cases and quantitative in others. Selective distribution systems have not been adequately assessed to determine whether or not they lead to an anti-competitive outcome on the market. ${ }^{38}$

Marsden and Whelan want the Commission to permanently consider consumers' desires and values. In particular, the Commission should be aware of those products where the pre-sales service is becoming less relevant for consumers and should not be hesitant in taking action where selective distribution does not lead to an increase in consumer welfare. ${ }^{39}$

With regard to exclusive distributions, Cox writes that allowing intrabrand competition via a non-exclusive distribution module has been proven in legal literature to be both beneficial to manufacturers as well as consumer interests. Intra-brand competition provides optimal incentives to the relevant competing distributors to work diligently, thus limiting costs and lead time while improving availability and the promotion of products. Also, the granting of exclusive territories to distributors has been proven to result in excessive price distortion being detrimental to consumer interests. This was experienced by Apple in the marketing of its first iPhone. ${ }^{40}$

\section{b) Rule of reason}

Many authors believe that the ECJ is adopting the United States' 'rule of reason' which allows the consideration of enhanced efficiencies achieved

\footnotetext{
${ }^{33}$ Wish and Bailey (n 4) 644.

${ }^{34}$ Jones and Sufrin (n 11) 666.

${ }^{35}$ Case C-56/65, Société Technique Minière v Maschinenbau Ulm GmbH [1966] ECR I-235 (249-250).

${ }^{36}$ Commission (n 5) para 151.

${ }^{37}$ Commission (n 5) para 153-4.

${ }^{38}$ Jones and Sufrin (n 11) 674.

${ }^{39}$ Marsden and Whelan (n 31) 35.

${ }^{40}$ MB Cox, 'Apple's exclusive distribution agreements: a refusal to supply?' [2012] ECLR $11(13-14)$.
} 
by potentially anti-competitive agreements in any case. ${ }^{41}$ For instance, Callery refers to the Wouters case ${ }^{42}$ where the ECJ found that 'despite the effects of restrictive competition that are inherent' in forbidding lawyers to work with accountants laid down by Bar Association regulations, 'it is necessary for the proper practice of the legal profession' in the Member State concerned. ${ }^{43}$ In their opinion, the Wouters case shows that the ECJ also considers non-competition factors, i.e. social and political concerns, besides any competition factors. This can also be seen in the Meca-Medina case ${ }^{44}$ where the ECJ assesses the restriction of competition under Art. 101(1) in the case of anti-doping rules and finally concludes that they are not anticompetitive because of their 'objective justification'. Therefore, Callery believes that the ECJ has widened the scope of justifiability by "public interest justifications'. ${ }^{45}$

\section{Competition law and Intellectual Property Rights (IPRs)}

The relationship between competition law and IPRs is sometimes not easy because IPRs give the innovator a legal monopoly and provide them with the right to exclusively exploit the innovation and exclude others from exploiting it. Both IPRs and competition law aim at protecting consumer welfare, the former by promoting technical progress and the latter by protecting competition as the driving force behind efficient markets, providing best quality products at the lowest price. ${ }^{46}$ Concentrating on vertical agreements, IPRs in the framework of licences or exclusive agreements should be discussed. Although the Commission says that companies should not be allowed to establish private barriers between Member States, ${ }^{47}$ the ECJ, especially in IPR cases, questions whether the barrier is justified. Besides Consten and Grundig ${ }^{48}$ this style of ECJ behaviour can be seen in different cases.

The Nungesser judgement shows some sensitivity to the commercial and economic context of licensing agreements. Thereafter, open exclusivity, whereby the licensor agrees not to grant licence to anyone else in the licensee's territory, does not necessarily infringe Art. 101(1) since the licensee accepts the risk of marketing a new product. ${ }^{49}$

With reference to the case law, Wish and Bailey conclude that in the situation of IPRs a more nuanced approach is required, so even absolute

\footnotetext{
${ }^{41}$ Alison Jones (n 19) 663. See also Craig Callery (n 19) 44.

${ }^{42}$ Case C-309/99, Wouters v Algemene Raad van de Nederlandse Orde van Advocaten [2002] ECR I-1577, para 110.

${ }^{43}$ Craig Callery (n 19) 48.

${ }^{44}$ Case C- 519/04 P, David Meca-Medina and Igor Majcen v Commission [2006] ECR I6991, para 45.

${ }^{45}$ Craig Callery (n 19) 48. For benefits and dangers in the extension of the Rule of Reason see Sandra Marco Colino, 'Vertical Agreements and Competition Law: A Comparative Study of the EU and US Regimes' (1 ${ }^{\text {st }}$ edn, Hart Publishing 2010) 145.

${ }^{46}$ Luc Peeperkorn, 'IP Licenses and Competition Rules: Striking the Right Balance' [2003] World Competition 527 (527-8).

${ }^{47}$ Commission (n 5) para 7.

${ }^{48}$ Etablissements Consten SA \& Grundig-Verkaufs-GmbH v Commission (n 10).

${ }^{49}$ Case C-258/78, L.C. Nungesser KG and Kurt Eisele v Commission [1982] ECR I-2015, para 68. See also Wish and Bailey (n 4) 775.
} 
territorial protection and export bans may not infringe Art. 101(1) in particular circumstances. ${ }^{50}$

\section{CONCLUSION}

The discussions above clearly demonstrate the following findings: Firstly, the Commission and the ECJ do not fully agree on the approach EU competition law should have. In the ECJ's arguments and judgements, hardcore restrictions do not occupy the role that the Commission represents in its new Guidelines - the Court applies its 'analytical approach' in any anticompetitive case. Secondly, most anti-competitive agreements fall outside Art. 101(1) because block exemptions 'presume', not prove by evidence, that companies with a market share below 30 per cent are unlikely to affect competition on the European market and that their distribution policy allows consumers a fair share of the resulting benefits. ${ }^{51}$ The minority with a market share above 30 per cent may escape infringement of Art. 101(1) either by 'objective justification', which must not be economic as the ECJ confirms in its cases, or may convince the ECJ that their anti-competitive behaviour is essential for product marketing, prevents free rides or is necessary for the exhaustion of their IPRs, etc.

Nevertheless, there are scholars who welcome the Commission's new Guidelines and the BER. ${ }^{52}$ It is, in fact, very reasonable and effective when, through the BER under Art. 3(1), 'both' buyers' and suppliers' anticompetitive practices are not to be exempted if the 30 per cent market share threshold is exceeded. But if the ECJ does not follow the Commission's views within its Guidelines in the future, which has occasionally occurred in the past, the effectiveness of the Guidelines and the Regulations would seriously be in doubt. Reciprocally, should the ECJ's 'analytical approach' sit within the Commission's 2010 new Guidelines, its 2004 Guidelines on Art. 81(3)

\footnotetext{
${ }^{50}$ Wish and Bailey (n 4) 776.

${ }^{51}$ Commission (n 6) Recital 8.

52 Wish and Bailey (n 2) 1790.
} 